ISSN: 2302-8556

E-Jurnal Akuntansi Universitas Udayana

Vol.22.3. Maret (2018): 1909-1935

DOI: https://doi.org/10.24843/EJA.2018.v22.i03.p10

\title{
Pengaruh Kapitalisasi Pasar Pada Manajemen Laba dengan Dewan Komisaris Independen dan Kualitas Auditor Sebagai Pemoderasi
}

\author{
Ida Ayu Widya Puspitasari ${ }^{1}$ \\ Ketut Muliartha $\mathbf{R M}^{2}$
}

${ }^{1}$ Fakultas Ekonomi dan Bisnis Universitas Udayana (Unud), Bali, Indonesia
email: iawidyapuspitasari@ yahoo.co.id/Telp: +62 8993103319
${ }^{2}$ Fakultas Ekonomi dan Bisnis Universitas Udayana (Unud), Bali, Indonesia

\begin{abstract}
ABSTRAK
Manajemen yang kinerjanya dilihat berdasarkan laba, menyadari adanya kecenderungan untuk lebih memperhatikan laba. Hal tersebut membuat manajemen dapat melakukan manajemen laba sebagai dampak dari masalah keagenan. Faktor pendorong manajemen laba adalah kapitalisasi pasar. Perbaikan pengelolaan perusahaan seperti menambah dewan komisaris independen dan kualitas auditor diperlukan guna menekan tindak manajemen laba tersebut. Penelitian ini mengambil sampel yaitu perusahaan sub sektor property dan real estate di Bursa Efek Indonesia periode 2012-2016 berdasarkan metode purposive sampling dengan total 126amatan. Pengumpulan data dilakukan dengan metode observasi non partisipan. Metode analisis dalam penelitian ini menggunakan analisis Moderated Regression Analysis.Hasil analisis menunjukkan bahwa kapitalisasi pasar tidak berpengaruh pada manajemen laba. Selain itu, dewan komisaris independen dan kualitas auditor tidak mampu memoderasi hubungan tersebut. Hal ini menunjukan ukuran kapitalisasi pasardan penerapan pengendalian internal maupun eksternal tidak memengaruhi terjadinya manajemen laba.
\end{abstract}

Kata kunci: Manajemen laba, kapitalisasi pasar, dewan komisaris independen, kualitas auditor

\begin{abstract}
Management performance based on profit tends to pay more attention on earning profit. it makes management can do earnings management as a result of agency problems. The driving factor of earnings management is market capitalization. Improvements on company management such as independent board of commissioners and auditor quality are necessary to suppress such earnings management. The sample of this research are property and real estate sub sector in Indonesia Stock Exchange period 2012-2016 based on purposive sampling method with total 126 observation. Data collection obtained by non participant observation method. Analysis method in this research is Moderated Regression Analysis.The results of the analysis shows that market capitalization has no effect on earnings management. Furthermore, independent board of commissioners and auditor quality is not able to moderate the relationship. It shows that size of market capitalization and application of internal and external controls do not affect the occurrence of earnings management.
\end{abstract}

Keywords: Earning management, market capitalization, independent board, auditor quality 


\section{PENDAHULUAN}

Bagi pihak internal dan eksternal, laporan keuangan merupakan sarana informasi yang penting dalam mengambil keputusan. Menurut Tariverdi et. al., (2012) dua karakter yang menjadikan informasi dalam laporan keuangan berguna adalah relevansi serta keandalan. Informasi yang disediakan menggambarkan hasil usaha yang tercemin melalui laba yang dihasilkan. Manajemen yang kinerjanya dilihat berdasarkan informasi laba, menyadari adanya kecenderungan untuk lebih memperhatikan laba (Prasetya, 2016). Hal tersebut membuat manajemen dapat melakukan prilaku mengatur laba sesuai dengan kemauannya yang dikenal dengan istilah sebutan manajemen laba.

Dampak dari masalah keagenan yang terjadi karena adanya perbedaan kepentingan antara pemegang saham atau principal dan manajemen perusahaan atau agent menimbulkan tindakan manajemen laba. Teori keagenan berasumsi bahwa setiap pihak yang terlibat bertindak untuk memaksimalkan kepentingan diri sendiri sehingga mendorong terjadinya konflik. Perselisihan kepentingan semakin meningkat karena principal tidak mengetahui secara keseluruhan mengenai informasi penting perusahaan yang berbanding terbalik dengan pihak agent yang jauh lebih mengetahui keadaan maupun informasi penting perusahaan.

Memilih prosedur akuntansi atau melalui transaksi akrual merupakan cara yang digunkanan manajer untuk dapat melakukan manajemen laba. Penggunaan basis akrual pada praktiknya dapat menimbulkan masalah dikarenakan dalam basis akrual 
ISSN: 2302-8556

E-Jurnal Akuntansi Universitas Udayana

Vol.22.3. Maret (2018): 1909-1935

terdapat discretionary accruals (DA). DA ialah akrual yang dipengaruhi oleh diskresi (keleluasaan) pihak manajemen. Tindakan tersebut jika tidak diungkapkan tentunya dapat menyebabkan penyimpangan penyampaian informasi dalam laporan keuangan.

Negara Indonesia ialah negara dengan tingkat manajemen labanya yang paling tinggi jika dibandingkan dengan negara anggota Association of South East Asia Nations (ASEAN) lainnya (Purnomo dan Pratiwi, 2009). Sedangkan menurut laporan Badan Pengawas Pasar Modal dan Lembaga Keuangan (Bapepam-LK), pada periode 2002-2003 terdapat 25 kasus pelanggaran pasar modal terkait praktik manajemen laba. Skandal akuntansi yang dilakukan Toshiba pada tahun 2015 dengan menggelembungkan laba usaha sebesar \$ 1.2 milyar selama tujuh tahun adalah kasus manajemen laba yang tengah menjadi fenomena akhir ini.

Terdapat beberapa faktor yang membuat manajer melakukan manajemen laba, salah satunya adalah ukuran perusahaan. Jumlah tenaga kerja, kapitalisasi pasar, total penjualan, total nilai aktiva, dan sebagainya merupakan proksi dari ukuran perusahaan (Hilmi dan Ali, 2008). Dalam penelitian ini, kapitalisasi pasar digunakan sebagai proksi ukuran perusahaan. Peningkatan kapitalisasi pasar merupakan prestasi bagi perusahaan, karena dengan menaikkan kapitalisasi pasar maka kemakmuran para pemilik serta pemegang saham juga akan meningkat. Perusahaan akanmemiliki insentif yang besar untuk melakukan manajemen laba, dikarenakan salah satu alasan utamanya ialah perusahaan harus mampu memenuhi expectations dari investor yang telah memberikan dananya, agar perusahaan menjaga konsistensi laba perusahaan. 
Penelitian yang dilakukan oleh Fitria (2015) serta Medyawati dan Dayanti (2016) menyebutkan bahwa ukuran perusahaan berpengaruh positif dengan manajemen laba. Namun sebaliknya, penelitian Herlambang (2015) dan Manggau (2016)menunjukan bahwa ukuran perusahaan berpengaruh negatif terhadap manajemen laba. Sedangkan di beberapa penelitian membuktikan ukuran perusahaan ternyata tidak berpengaruh terhadap manajemen laba seperti yang dilakukan olehPradito dan Rahayu (2015), Gunawan et al. (2015). Dari penelitian sebelumnya tersebut menunjukan hasil yang berubah-ubah (inkonsisten). Hasil inkonsisten ini dapat disebabkan oleh faktor lain yang memperkuat ataupun memperlemah pengaruh ukuran perusahaan dengan manajemen laba, yang dalam hal ini berbentuk sebuah pengendalian internal dan eksternal perusahaan.

Manajemen laba dapatt diminimumkan serta dapat meningkatkan kualitas laporan keuangan, maka perlu dilaksanakan tata kelola perusahaan yang baik atau yang disebut Good Corporate Governance (GCG) yang dalam penelitian diproksikan dalam dewan komisaris independen. Posisi terbaik untuk melaksanakan tugas monitoring guna tercipta perusahaan yang GCGialah dewan komisaris independen(Ujiyantho dan Pramuka, 2007). Adanya dewan komisaris independenbetugas memberikan pengawasan terhadap kinerja perusahaan yangtercermin dari kualitas pelaporan yang dihasilkan.

Pengendalian terhadap laporan keuangan akan semakin bagus dengan adanya auditor. Kualitas audit yang baik sangat diharapkan karena dapat mengembalikan 
ISSN: 2302-8556

E-Jurnal Akuntansi Universitas Udayana

Vol.22.3. Maret (2018): 1909-1935

kepercayaan pihak pengguna laporan keuangan (Luhgiatno, 2010). Tindakan manajemen laba yang dilakukan klien dapat dideteksi dengan adanya auditor yang berkualitas. DeAngelo (1981) menyatakan bahwa kualitas audit yang dilakukan oleh akuntan publik dapat dilihat dari ukuran Kantor Akuntan Publik (KAP) yang melakukan audit. Klien biasanya mempersepsikan bahwa auditor yang berasal dari KAP besar dan berafiliasi dengan KAP internasional memiliki kualitas yang lebih tinggi karena auditor tersebut memiliki karakteristik yang dapat dikaitkan dengan kualitas seperti pelatihan, pengakuan internasional, serta adanya peer review(Crasswell, 1998).

Berlandaskan latar belakang yang dipaparkan di atas, maka penelitian ini mengangkat judul "Pengaruh Kapitalisasi Pasar pada Manajemen Laba dengan Dewan Komisaris Independen dan Kualitas Auditor sebagai Pemoderasi’. Rumusan masalah yang dapat diangkat: 1) Apakah kapitalisasi pasar berpengaruh pada manajemen laba?, 2) Apakah kapitalisasi pasar berpengaruh pada manajemen laba dengan dewan komisaris independen sebagai pemoderasi?, dan 3) Apakah kapitalisasi pasar berpengaruh pada manajemen laba dengan kualitas auditor sebagai pemoderasi?

Tujuan dilakukannya penelitian ini ialah untuk menguji serta memberikan bukti empiris dewan komisaris independen dan kualitas auditor memoderasi pengaruh kapitalisasi pasar terhadap manajemen laba. Penelitian yang dilakukan ini dapat memberikan manfaat yaitu manfaat teoritis dan praktis. Manfaat teoritis, penelitian ini mampu memberikan kontribusi dalam bentuk bukti empiris serta dapat 
memberikan sumbangan pemikiran berkaitan dengan teori keagenan dalam pengaruh kapitalisasi pasar pada manajemen laba dengan dewan komisaris independen dan kualitas auditor sebagai pemoderasi. Manfaat praktisnya, dapat memberi manfaat serta informasi tambahan tentang pengaruh kapitalisasi pasar, dewan komisaris independen dan kualitas auditor pada manajemen laba sehingga dapat dijadikan bahan pertimbangan bagi perusahaan maupun investor.

Grand teori pada penelitian ini ialah teori keagenan. Jensen dan Meckling (1976) menceritakan ketika satu orang atau lebih (principal) mempekerjakan orang lain (agent) yang menimbulkan suatu kontrak serta memunculkan hubungan agensi. Hubungan tersebut akan memungkinkan terjadinya konflik kepentingan (conflict of interest) antara principal dan agent(Ross et al., 2010). Perselisihan kepentingan antara principal dan agent akan mendorong timbulnya biaya keagenan (agency cost).

Manajemen laba merupakan pilihan yang dilaksanakan oleh manajer dalam menentukan kebijakan akuntansi agar mencapai beberapa tujuan tertentu (Dumbi, 2010). Manajer bisa terlibat dengan memodifikasi tentang bagaimana cara menginterpretasikan berbagai standar akuntansi keuangan dan data akuntansi (Healy dan Wahlen, 1999). Menurut Scott (2012), terdapat beberapa lima motivasi manajer sebuah perusahaan melaksanakan manajemen laba, yakni mekanisme bonus, motivasi politik, motivasi kontraktual lainnya, motivasi perpajakan, pergantian Chief Executive Officer (CEO) dan Initial Public Offering (IPO). Terdapat empat pola 
ISSN: 2302-8556

E-Jurnal Akuntansi Universitas Udayana

Vol.22.3. Maret (2018): 1909-1935

manajemen laba yang dapat dilakukan oleh manajer yakni income minimization, income maximization, income smoothing dan taking a bath.

Ukuran perusahaan merupakan perbandingan besar atau kecilnya suatu perusahaan berdasarkan kriteria tertentu. Semakin besar kemampuan perusahaan untuk melakukan operasi, mempengaruhi pasar, dan menghasilkan laba maka ukuran perusahaan juga semakin makin besar (Crisóstomo et al., 2013). Manurung dan Rizky (2009) menyatakan bahwa saham berkapitalisasi besar jika bernilai di atas Rp 1 triliun, saham berkapitalisasi menengah bernilai Rp 100 miliar sampai dengan kurang dari Rp 1 triliun, sedangkan saham berkapitalisasi kecil memiliki nilai dibawah Rp 100 miliar.

Salah satu proksi dari GCG ialah dewan komisaris independen. Keanggotaan dewan komisaris independen berasal dari luar perusahaan yang tidak memiliki hubungan odengan pihak manajemen, dewan komisaris lainnya dan pemegang saham pengendali. Berdasarkan Keputusan Direksi PT Bursa Efek Jakarta Nomor: Kep305/BEJ/07-2004 tentang Pencatatan Saham dan Efek Bersifat Ekuitas serta Peraturan Otoritas Jasa Keuangan (OJK) menjelaskan bahwa setiap perusahaan publik diwajibkan mempunyai komisaris independen sekurang-kurangnya $30 \%$ dari jajaran anggota dewan komisaris.

Audit terdiri atas investigasi terhadap jurnal akuntansi dan fakta lain yang mendukung laporan keuangan (Whittington et al., 2012). AAA Financial Accounting Standar Committee (2000) menjelaskan bahwa kompetensi dan independensi 
merupakan 2 hal untuk menentukan kualitas audit. Kompetensi auditor dilihat keahlian auditor untuk mendapatkan salah saji yang material dalam laporan keuangan perusahaan sedangkan independensi dapat dilihat dari kemauan auditor untuk mengungkapkan temuan salah saji tersebut. Kepercayaan besar pemakai laporan keuangan yang telah diaudit, akhirnya mengharuskan KAP memperhatikan kualitas audit yang dihasilkannya. Pembaca maupun pemakai laporan keuangan menganggap bahwa auditor dari KAP besar dan berhubungan dengan KAP internasional memiliki kualitas yang lebih baik karena memiliki karakteristik yang dapat dikaikan dengan kualitas seperti pelatihan, pengakuan internasional, serta adanya peer review(Crasswell, 1998).

Studi dilakukan Kim et al. (2003)menunjukkan bahwa ukuran perusahaan memiliki hubungan kuat pada manajemen laba perusahaan. Bertambah besar kapitalisasi pasar, membuat hubungan antara principal dan agent pun semakin kompleks dan menyebabkan timbunya biaya keagenan. Teori keagenanmenjelaskan perusahaan berukuran besar memiliki biaya keagenan yang makin besar dan ini berarti praktik oportunistik yang lebih banyak. Praktik oportunistik yang dilakukan oleh manajer melalui pengaturan laba atau yang dikenal dengan istilah manajemen laba. Ali et al. (2015), Jahmani dan Niranjan, (2015), Uwuigbe et al. (2015)serta Medyawati dan Dayanti (2016) menemukan hasil bahwa ada pengaruh positif antara ukuran perusahaan pada manajemen laba.

$\mathrm{H}_{1}$ : Kapitalisasi pasar berpengaruh positif pada manajemen laba 
ISSN: 2302-8556

E-Jurnal Akuntansi Universitas Udayana

Vol.22.3. Maret (2018): 1909-1935

Kapitalisasi pasar menunjukan seberapa besar kemampuan perusahaan untuk menghasilkan laba. Laba merupakan indicator guna menaksirkan kinerja manajemen. Manajer yang kemampuannya dilihat berdasarkan laba maka akan cenderung untuk peduli terhadap laba yang dihasilkan. Maka dari itu, dapat memicu terjadi manajemen laba dalam perusahaan dikarena adanya konflik kepentingan dari hubungan agensi antara principal dan agent. Manajemen laba dapat dikecilkan melalui suatu proses pengawasan dengan tujuanuntuk menyamakan berbagaikepentingan(Ujiyantho dan Pramuka, 2007).Dewan komisari independen merupakan struktur organisasi internal perusahaan yang memiliki fungsi pengawasan dan dapat meminimalisir konfik kepentingan karena akan bersikap objektif dalam pengambilan keputusan.Penelitian terkait pengaruh tersebut telah dilakukan olehNariastiti dan Dwi Ratnadi (2014), Herlambang (2015), serta Pradito dan Rahayu (2015).

$\mathrm{H}_{2}$ : Dewan komisaris independen memperlemah pengaruh kapitalisasi pasar pada manajemen laba

Semakin besar kapitalisasi pasar, membuat pemegang saham kian sulit mengontrol dan memonitor perusahaan secara menyeluruh. Ketidakseimbangan informasi anatara principal dan agent dapat menimbulkan permasalahan dalam perusahaan. Kelemahan ini memberikan peluang bagi pihak manajemen untuk melakukan manajemen laba (Manggau, 2016). Teori keagenan juga dipergunakan untuk menjelaskan kebutuhan akan audit (Putra Astika, 2010). Pemeriksaan eksternal dapat menekan terjadinya perbedaan informasi antara kedua belah pihak tersebut 
dengan melakukan verifikasi dan validasi laporan keuangan yang disajikan. Semakin tinggi kualitas audit yang menggunakan ukuran KAP (KAP The BigFour) maka semakin rendah manajemen laba yang terjadi di perusahaan tersebut (Herusetya, 2009). Terkait pengaruh tersebut telah dilakukan penelitian oleh Gerayli et al., (2011), Chen et al. (2013) serta Sugiarti (2014). Berdasarkan uraian tersebut, maka hipotesis ketiga ialah.

$\mathrm{H}_{3}$ : Kualitas auditor memperlemah pengaruh kapitalisasi pasar pada manajemen laba

\section{METODE PENELITIAN}

Bentuk pendekan yang digunakan bersifat asosiatif. Obyek penelitian dalam kajian penelitian ini ialah manajemen laba, kapitalisasi pasar, dewan komisaris independen dan kualitas auditor. Penelitian ini dilakukan pengujian variabel kapitalisasi pasar pada manajemen laba dengan dewan komisaris independen dan kualitas auditor sebagai pemoderasi. Variabel bebas atau independen(X) ialah variabel yang mempengaruhi timbulnya variabel terikat. Penelitian ini menggunakan varibel bebas yaitu kapitalisasi pasar. Kapitalisasi pasar menggambarkan total nilai pasar dari perusahaan dengan mengalikan harga saham dengan jumlah saham yang beredar (Deitiana, 2015).

Variabel terikat atau dependen (Y) adalah variabel yang dipengaruhi karena adanya variabel bebas. Manajemen laba ialah varibel terikat penelitian ini. 
ISSN: 2302-8556

E-Jurnal Akuntansi Universitas Udayana

Vol.22.3. Maret (2018): 1909-1935

Perhitungan discretionary accrual (DA) menggunakan Modified Jones Model dilakukan untuk mengidentifikasi kemungkinan adanya praktik manajemen laba.

Variabel moderasi $(Z)$ adalah variabel yang mempengaruhi hubungan antara variabel independen dan variabel dependen yaitu dewan komisaris independen dan kualitas auditor. Dewan komisaris independen $\left(Z_{1}\right)$ dihitung dengan membagi jumlah anggota komisaris independen dengan jumlah seluruh anggota dewan komisaris. Kualitas auditor $\left(\mathrm{Z}_{2}\right)$ diukur dengan ukuran KAP dimana KAP Big Four maka akan diberikan nilai 1, dan jika menggunakan KAP Non Big Four diberikan nilai 0 (Sugiarti, 2014). KAP di Indonesia yang berafiliasi dengan Big Four adalah: 1) KAP Purwantono, Suherman \& Surja - affiliate of Ernst \& Young, 2) KAP Osman Bing Satrio - affiliate of Deloitte, 3) KAP Siddharta Widjaja \& Rekan - affiliate of KPMG, 4) KAP Tanudiredja, Wibisana, Rintis \& Rekan - affiliate of PwC

Populasi dalam penelitian ini ialah perusahaan sub sektor property dan real estate yang terdaftar di Bursa Efek Indonesia (BEI) periode 2012-2016 dengan total 53 perusahaan untuk satu periode dengan jumlah populasi selama lima tahun sebanyak 265. Penentuan sampel menggunakan teknik purposive sampling. Metode pengumpulan data ialah dengan observasi non partisipan atau tanpa ikut terlibat dari kejadian yang diamati (Sugiyono, 2014) dengan mengakses website resmi BEI maupun mengakses situs internet serta uraian dari buku-buku, karya ilmiah, skripsi, jurnal. 
Penelitian ini menggunakan jenis data kuantitatif dan kualitatif. Data kuantitatif berasal dari laporan keuangan perusahaan seperti laba bersih, kas, total asset, pendapatan, piutang, kapitalisasi pasar dan sebagainya. Data kualitatif berupa pandangan dari penelitian sebelumnya serta gambaran umum perusahaan yang dipublikasikan dalam laporan tahunan perusahaan seperti nama KAP.

Penelitian ini menggunakan data sekunder yaitu laporan tahunan yang didalamnya terdapat laporan keuangan yang telah diaudit. Pada penelitian ini analisis regresi yang digunakan adalah Moderated Regression Analysis (MRA). Sebelum analisis data, tahap awal yang dilaksanakan ialah uji asumsi klasik meliputi uji normalitas, autokorelasidan heterokedastisitas lalu statistik deskriptif, setelah itu Moderated Regression Analysis (MRA) serta dilanjutkan dengan mencari koefisien determinasi $\left(\mathrm{R}^{2}\right)$, uji kelayakan model dan uji signifikansi parameter individual.Persamaan regresi penelitian ini disusun sebagai berikut :

$$
Y=\alpha+\beta_{1} X+\beta_{2} Z_{1}+\beta_{3} Z_{2}+\beta_{4} X^{*} Z_{1}+\beta_{5} X^{*} Z_{2}+e
$$

Keterangan :

$\mathrm{Y} \quad=$ Manajemen laba

$\alpha \quad=$ Konstanta

$\beta_{1}-\beta_{5}=$ Koefisien regresi

$\mathrm{X} \quad=$ Kapitalisasi pasar

$\mathrm{Z}_{1} \quad=$ Dewan komisaris independen

$\mathrm{Z}_{2} \quad=$ Kualitas auditor

$\beta_{4} X^{*} Z_{1}=$ Interaksi antara kapitalisasi pasar dengan dewan komisaris indenden

$\beta_{5} \mathrm{X} * \mathrm{Z}_{2}=$ Interaksi antara kapitalisasi pasar dengan kualitas auditor

$\mathrm{e} \quad=$ Error atau variabel pengganggu 
ISSN: 2302-8556

E-Jurnal Akuntansi Universitas Udayana

Vol.22.3. Maret (2018): 1909-1935

\section{HASIL DAN PEMBAHASAN}

Penelitian ini melakukan pemilihan sampel menggunakan metode purposive sampling dengan beberapa kriteria. Pengambilan sampel penelitian ini digambarkan pada Tabel 1.

\section{Tabel 1.}

Ringkasan Perolehan Sampel Penelitian

\begin{tabular}{llc}
\hline No. & Keterangan & Jumlah \\
\hline 1. & $\begin{array}{l}\text { Perusahaan sub sektor property dan real estate yang terdaftar di BEI pada } \\
\text { periode 2012-2016 }\end{array}$ & 53 \\
2. $\quad \begin{array}{l}\text { Perusahaan sub sektor property dan real estate yang tidak terdaftar secara } \\
\text { konsisten di BEI selama tahun 2012-2016 }\end{array}$ & $(6)$ \\
3. Perusahaan sub sektor property dan real estate yang tidak mempublikasikan & $(9)$ \\
$\quad$ laporan tahunan dan laporan keuangan untuk periode 31 Desember tahun 2012- & \\
2016 & $(8)$ \\
Jumlah perusahaan yang dijadikan obyek penelitian & 30 \\
Total sampel dalam penelitian dengan periode waktu selama 5 tahun & 150 \\
Perusahaan yang memiliki data outlier & $(24)$ \\
\hline Total sampel pengamatan & 126 \\
\hline Sumber:Data diolah, 2017 &
\end{tabular}

Dilanjutkan dengan statistik deskriptif guna memberikan gambaran varibel penelitian yang hasilnya dapat dilihat pada Tabel 2. Manajemen laba (Y) memiliki nilai mean yang menunjukkan nilai positif menandakan bahwa sebagaian besar perusahaan terindikasi melakukan manajemen laba dengan income increasing (meningkatkan laba).Nilai terkecil sebesar -0,16dan terbesar sebesar 0,25. Kapitalisasi pasar (X) memiliki nilai rata-rata sebesar 28,7390yang artinya perusahaan sebagian besar berkapitalisasi besar. Nilai paling rendah sebesar 24,22 dan terbesar bernilai 31,18 . Nilai rerata dewan komisaris independen $\left(Z_{1}\right)$ sejumlah 0,3662 menjelaskan sebagain besar perusahaan telah menaati Keputusan Direksi BEJ 
danPeraturan OJK. Nilai terkecil dan terbesar sebesar 0,00 dan 0,75. Nilai mean kualitas auditor $\left(\mathrm{Z}_{2}\right)$ sebesar 0,2460 menunjukan bahwa perusahaan sebagain besar menggunakan KAP Non Big Four guna memeriksa laporan keuangan perusahaan. Nilai terkecil sebesar 0.00 dan paling tinggi sebesar 1.00. Tabel 2 melihatkan bahwa semua nilai deviasi standar masing-masing variabel tidak melewati dua kali nilai mean yang menandakan bahwa sebaran data telah baik.

Tabel 2.

\begin{tabular}{lccccc}
\multicolumn{7}{c}{ Hasil Uji Statistik Deskriptif } & & \\
\hline & N & Minimum & Maximum & Mean & $\begin{array}{c}\text { Std. } \\
\text { Deviation }\end{array}$ \\
\hline Manajemen Laba & 126 & $-0,16$ & 0,25 & 0,0551 & 0,06886 \\
Kapitalisasi Pasar & 126 & 24,22 & 31,18 & 28,7390 & 1,54568 \\
$\begin{array}{l}\text { Dewan Komisaris } \\
\text { Independen }\end{array}$ & 126 & 0,00 & 0,75 & 0,3662 & 0,11335 \\
Kualitas Auditor & 126 & 0,00 & 1,00 & 0,2460 & 0,43242 \\
$\begin{array}{l}\text { Moderasi Dewan } \\
\text { Komisaris Independen }\end{array}$ & 126 & 0,00 & 23,01 & 10,4154 & 3,51851 \\
$\begin{array}{l}\text { Moderasi Kualitas } \\
\text { Auditor }\end{array}$ & 126 & 0,00 & 30,84 & 6,9901 & 12,56005 \\
Valid N (listwise) & 126 & & & & \\
\hline Sub: Datadiolat, 2017 & & & & &
\end{tabular}

Sumber: Data diolah, 2017

Uji asumsi klasik adalah uji pendahuluan sebelum dilakukannya analisis regresi. Berikut adalah pembahasan dari uji asumsi klasik untuk keseluruhan sampel yang telah dilakukan.

Uji normalitas bertujuan untuk menguji apakah dalam model regresi, variabel pengganggu atau residual memiliki distribusi normal. Nilai asymp. sig (2-tailed) pada penelitian ini adalah sebesar 0,200. Nilai tersebut lebih besar dari 0,05, menunjukkan bahwa data yang diuji berdistribusi normal. 
Autokorelasi ialah korelasi yang terjadi diantara varibel dari serangkaian pengamatan yang tersusun dalam rangkaian deret waktu. hasil uji autokorelasi dalam penelitian ini. Hasil autokorelasi memperlihatkan nilai $d=1,743$ dengan $\mathrm{dl}=1,6608$ dan $\mathrm{du}=1,7582$ untuk jumlah sampel 126 dengan tiga variabel bebas (k) serta $\alpha=5 \%$. Hasil autokorelasi menjadi $1,6608 \leq 1,743 \leq 1,7582$ yang berarti tidak ada keputusan terhadap hasil tersebut sehingga dilakukan Uji Runs. Hasil uji Runs menunjukkan nilai signifikan 0,371 lebih besar dari $\alpha=0,05$, sehingga model ini tidak mengandung gejala autokorelasi.

Uji heteroskedastisitas bertujuan menguji apakah dalam model regresi terjadi ketidaksamaan varians dari residual satu pengamatan ke pengamatan lain. Hasil memperlihatkan tidak terjadi heteroskedastiaitas. Hal ini dapat dilihat pada tampilan output SPSS yang menunjukkan bahwa tidak ada variabel yang probabilitas signifikannya diatas tingkat kepercayaan $5 \%$.

Berdasarkan hasil pemaparan diatas, diketahui bahwa data dalam penelitian ini terdistribusi normal, tidak ada autokorelasi dan tidak terjadi heteroskedastisitas. Data yang tersedia telah memenuhi syarat untuk menggunakan model regresi yaitu MRA. Model MRA dengan bantuan SPSS versi 22.0 serta diuji dengan tingkat signifikansi 5\% hasil ujinya ditunjukkan oleh Tabel 3. 
Tabel 3.

Hasil Analisis Moderated Regression Analysis

\begin{tabular}{|c|c|c|c|c|c|}
\hline \multirow{2}{*}{ Model } & \multicolumn{2}{|c|}{$\begin{array}{l}\text { Unstandardized } \\
\text { Coefficients }\end{array}$} & \multirow{2}{*}{$\begin{array}{l}\text { Standardized } \\
\text { Coefficients } \\
\text { Beta }\end{array}$} & \multirow[t]{2}{*}{$\mathbf{T}$} & \multirow[t]{2}{*}{ Sig. } \\
\hline & $\mathbf{B}$ & $\begin{array}{l}\text { Std. } \\
\text { Error }\end{array}$ & & & \\
\hline (Constant) & 0,133 & 0,189 & & 0,701 & 0,484 \\
\hline Kapitalisasi Pasar & $-0,003$ & 0,007 & $-0,063$ & $-0,416$ & 0,678 \\
\hline $\begin{array}{l}\text { Dewan Komisaris } \\
\text { Independen }\end{array}$ & 0,010 & 0,531 & 0,016 & 0,019 & 0,985 \\
\hline Kualitas Auditor & 0,192 & 0,358 & 1,208 & 0,537 & 0,592 \\
\hline $\begin{array}{l}\text { Moderasi Dewan Komisaris } \\
\text { Independen }\end{array}$ & $-0,001$ & 0,018 & $-0,045$ & $-0,048$ & 0,962 \\
\hline Moderasi Kualitas Auditor & $-0,006$ & 0,012 & $-1,029$ & $-0,461$ & 0,646 \\
\hline Adjusted R Square & \multicolumn{2}{|c|}{0,056} & & & \\
\hline$F_{\text {hitung }}$ & \multicolumn{2}{|c|}{2,475} & & & \\
\hline Signifikansi F & \multicolumn{2}{|c|}{$0,036^{\mathrm{b}}$} & & & \\
\hline
\end{tabular}

Berdasarkan Tabel 3, dapat disusun persamaan regresi sebagai berikut:

$Y=0,133-0,003 X_{1}+0,010 Z_{1}+0,192 Z_{2}-0,001 X * Z_{1}-0,006 X * Z_{2}$

Bedasarkan Tabel 3, nilai Adjusted $R$ Square adalah 0,056. Hal tersebut berarti 5,6\% variabel manajemen laba (Y) dapat dijelaskan oleh kapitalisasi pasar (X), dewan komisaris independen $\left(\mathrm{Z}_{1}\right)$ dan kualitas auditor $\left(\mathrm{Z}_{2}\right)$, sedangkan sisanya yaitu sebesar 94,4\% dijelaskan oleh variabel-variabel lain di luar model. Selain itu, nilai signifikansi $\mathrm{F}$ sebesar 0,036 yang lebih kecil dari taraf signifikansi 5\%. Dengan demikian, model persamaan dalam penelitian ini layak untuk digunakan.

Tabel 3, menjelaskan pula hasil pengujian secara individual variabel independen. Variabel kapitalisasi pasar,dewan komisaris independen, kualitas auditor, pemoderasi dewan komisaris independen dan pemoderasi kualitas auditor memiliki nilai signifikansi lebih besar dari $\alpha=5 \%$. Hasil ini menunjukkan bahwa seluruh 
variabel independen dan moderasi tidak berpengaruh signifikan pada manajemen laba.

Hasil ini menolak hipotesis pertama $\left(\mathrm{H}_{1}\right)$ dan menjadikan sebuh bukti empiris bahwa besar, menengah atau kecil kapitalisasi pasar tidak mempengaruhi tindakan manajemen melakukan pengaturan laba atau manajemen laba. Hasil pengujian ini mengidentifikasikan bahwa perusahaan berkapitalisasi pasar besar hampir seluruhnya melakukan manajemen laba. Hal ini sejalan dengan teori keagenanyang menjelaskan bahwa perusahaan berukuran besar memiliki biaya keagenan yang lebih besar dan berarti praktik manajemen laba yang lebih banyak(Jensen dan Meckling, 1976). Biaya keagenan timbul akibat hubungan antara principal dan agent yang semakin kompleks di perusahaan berukuran besar.

Ukuran perusahaan yang diproksikan dalam kapitalisasi pasar belum mampu menjadi parameter yang digunakan investor untuk menilai kinerja perusahaan. Faktor yang mempengaruhi kinerja perusahaan adalah manajemen laba (Theresia, 2005). Penelitian yang dilakukan Faozi (2003)mengungkapkan bahwa terdapat faktor lain yang lebih penting untuk dipertimbangkan dalam pengambilan keputusan investasi seperti tingkat keuntungan, prospek usaha perusahaan dimasa yang akan datang dan lain sebagainya.

Hasil pengujian ini mengidentifikasikan bahwa perusahaan sub sektor property dan real estate mempunyai perilaku yang sama antara perusahaan besar maupun kecil dan tidak mendukung movitasi politik dalam praktik manajemen laba. 
Motivasi politik menjelaskan bahwa perusahaan berukuran besar akan berusaha untuk mengecilkan laba guna mengurangi visibilitasnnya. Jika dilihat pada perilaku perusahaan dengan nilai terbesar kapitalisasi pasar yaitu 31,18 sedangkan untuk nilai manajemen laba sebesar 0,1 jauh lebih besar dari rerata yaitu 0,0551. Hal ini menjelaskan jika ukuran perusahaan yang besar melakukan income increasing (meningkatkan laba) dalam praktik manajemen labanya. Llukani (2013), Waweru dan Riro (2013), Gunawan et al. (2015), Pradito dan Rahayu (2015), dan Bassiouny et al. (2016) telah melakukan penelitian dengan hasil yang sama bahwa ukuran perusahaan tidak berpengaruh dengan manajemen laba.

Hasil ini menolak hipotesis kedua $\left(\mathrm{H}_{2}\right)$ dan menjadikan bukti bahwa banyak atau sedikitnya komposisi dewan komisaris independen belum dapat memoderasi pengaruh kapitalisasi pasar pada manajemen laba dalam perusahaan. Kapitalisasi pasar menunjukan seberapa besar kemampuan perusahaan untuk menghasilkan laba. Laba yang dihasilkan dapat memotivasi terjadi manajemen laba dalam perusahaan sehingga dibutuhkan fungsi monitoring terhadap eksekutif, yang dijalankan oleh dewan komisaris independen. Penelitian yang dilakukan Ujiyantho dan Pramuka (2007) mengungkapkan bahwa dewan komisaris independen bukan faktor utama yang menjadi penentu keefektivitas pengawasan manajemen laba pada suatu perusahaan.

Dewan komisaris independen dalam melaksanakan tugas serta tanggung jawab atas monitoring kualitas informasi dalam laporan keuangan menghandapi berbagai kendala. Komisaris independen tidak memiliki informasi memadai karena 
ISSN: 2302-8556

E-Jurnal Akuntansi Universitas Udayana

Vol.22.3. Maret (2018): 1909-1935

terhalang oleh kedudukan direksi yang sangat besar (Effendi, 2009). Masih lemahnya kemampuan dan integritas dewan komisaris independen untuk mengawasi kinerja manajemen juga menjadi kendala yang cukup menghambat (Oktaviani, 2015). Padahal integritas adalah dasar agar penerapan GCG dapat terlaksana secara efektif dalam suatu perusahaan.penempatan komisaris independen dalam perusahaan juga hanya sekedar untuk memenuhi ketentuan formal (Effendi dan Daljono, 2013). Banyak atau tidak dewan komisaris independen tidak mampu mendorong perusahaan untuk mengimplementasikan GCG dengan baik sehingga belum dapat memperlemah maupun memperkuat hubungan kapitalisasi pasar pada manajemen laba.

Hasil ini menolak hipotesis ketiga $\left(\mathrm{H}_{3}\right)$ dan menunjukkan bahwa tinggi rendah kualitas audit yang dilihat menggunakan ukuran KAP belum dapat memoderasi pengaruh kapitalisasi pasar pada manajemen laba dalam perusahaan.Besarnya kapitalisasi pasarmembuat pemegang saham kian sulit mengontrol perusahaan secara menyeluruh. Hal tersebut dikarenakan principalmemiliki informasi yang lebih sedikit dibandingkan dengan agent sehingga memberikan peluang untuk melakukan manajemen laba. Teori keagenan juga dipergunakan untuk menjelaskan kebutuhan akan audit (Putra Astika, 2010). Pemeriksaan eksternal dapat menekan terjadinya perbedaan informasi antara kedua belah pihak tersebut dengan melakukan verifikasi dan validasi laporan keuangan yang disajikan.

Kualitas auditor yang diproksikan dengan ukuran KAP kurang tepat digunakan di Indonesia (Sandra dan Kusuma, 2004). Kompetensi dan independensi 
merupakan faktor lain yang lebih mempengaruhi kualitas audit selain faktor ukuran KAP. Kemampuan mendeteksi manajemen laba akan rendah apabila ukuran KAP yang besar tidak dibarengi dengan kompetensi yang tinggi dari auditornya (Nindita dan Siregar, 2013).

Berdasarkan lampiran 5 terlihat bahwa 53,3\% perusahaan sampel tidak melakukan pergantian KAP selama lima tahun berturut-turut. Tidak melakukan pergantian KAP juga dapat menjadi sebab tidak berpengaruhnya kualitas auditor dalam hubungan kapitalisasi pasar dengan manajemen laba. Jiang et al. (2008) menemukan bahwa independensi KAP yang menurun membuat KAP tidak mampu mendeteksi kecurangan pelaporan disebabkan salah satu faktornya adalah semakin lama hubungan antara auditor dengan klien membuat.Dengan demikian, baik itu ukuran KAP belum dapat memperlemah maupun memperkuat hubungan kapitalisasi pasar pada manajemen laba.

Berdasarkan pembahasan yang telah diuraikan, diharapkan dapat memberikan kontribusi positif bagi semua pihak khususnya pihak investor dan perusahaan. Bagi pihak perusahaan hendaknya bersungguh-sungguh dalam penerapan dari GCG baik itu internal maupun eksternal. Perusahaan juga diharapkan dapat menerapkan GCG dan pemeriksaan auditor eksternal secara sungguh-sungguh bukan untuk memenuhi ketentuan formal saja. Hal ini penting karena bagi pihak eksternal dapat memberikan gambaran tentang penerapan GCG di dalam perusahaan dan menjadi nilai tambah dimata investor. 
ISSN: 2302-8556

E-Jurnal Akuntansi Universitas Udayana

Vol.22.3. Maret (2018): 1909-1935

Bagi pihak investor dalam berinvestasi tetap memperhatikan kapitalisasi pasar, dewan komisaris independen dan kualitas auditor dari perusahaan, karena dilihat dari koefisien determinasi sebesar 5,6\% dapat menjelaskan praktik manajemen laba di dalam perusahaan. Investor yang akan berinvestasi juga tetap memperhatikan aspek non financial yaitu penerapan GCG perusahaan, hal ini penting karena dengan aspek tersebut dapat mengetahui pengawasan di dalam perusahaan yang dapat memengaruhi kualitas laporan keuangan khususnya laba yang dilaporkan.

\section{SIMPULAN}

Berdasarkan analisis data dan pembahasan yang telah dilakukan, dapat diambil simpulan bahwa kapitalisasi pasar tidak berpengaruh pada manajemen laba. Kapitalisasi pasar belum mampu menjadi dasar yang digunakan investor dalam menilai kinerja perusahaan yang didalamnya terdapat manajemen laba. Dewan komisaris independen tidak mampu memoderasi hubungan kapitalisasi pasar pada manajemen laba. Banyak tidaknya dewan komisaris independen tidak mampu mendorong perusahaan untuk melaksanakan GCG dengan baik dalam perusahaan. Kualitas auditor tidak mampu memoderasi hubungan kapitalisasi pasar pada manajemen laba. KAP Big Four maupun Non Big Four sebagai proksi kualitas auditor kurang tepat diterapkan di Indonesia serta sebagaian perusahaan tidak melakukan pergantian KAP membuat menurunnya kemampuan auditor mendeteksi manajemen laba dalam suatu perusahaan. 
Saran yang diusulkan peneliti berdasarkan simpulan hasil penelitian di atas yaitu bagi penelitian selanjutnya diharapkan dapat menamah diharapkan dapat memperluas sampel dengan obyek penelitian seperti menambah sektor manufaktur maupun sektor lain di BEI agar dapat menggambarkan kondisi seluruh perusahaan yang ada di Indonesia. Selain itu, nilai koefisien determinasi dari model ini yang relatif kecil maka sebaiknya untuk selanjutnya dapat menambahkan variabel lain seperti dewan dereksi dan kepemilikan institusional.

Bagi perusahaan, diharapkan untuk lebih bersungguh-sungguh dalam menerapkan GCG baik itu internal maupun pemeriksaan auditor eksternal. Perusahaan juga dianjurkan untuk ikut melaksanakan GCG dengan benar bukan sekedar formalitas peraturan. Hal ini menjadi penting karena bagi pihak eksternal dapat memberikan gambaran tentang penerapan GCG di dalam perusahaan dan dapat menjadi nilai tambah dimata investor.Bagi investor, dalam mengambil keputusan dalam berinvestasi, harus mampu menyimak laporan keuangan yang dipublikasikan di BEI agar mengetahui indikasi terjadinya manajemen laba. Selain itu, sebaiknya investor juga tidak hanya melihat dari informasi keuangannya saja melainkan juga tetap melihat aspek non keuangan seperti penerapan GCG yang dilakukan oleh perusahaan serta auditor eksternal yang memeriksa laporan keuangan perusahaan. Jika hal tersebut telah terlaksanakan dengan baik, maka bisa menjadi jaminan bentuk pengawasan dan control perusahaan baik pula. Hal ini sebagai salah satu cara untuk menekan tindakan oportunistik manajemen. 
ISSN: 2302-8556

E-Jurnal Akuntansi Universitas Udayana

Vol.22.3. Maret (2018): 1909-1935

\section{REFRENSI}

AAA Financial Accounting Standar Committee. 2000. Commentary: SEC Auditor Independence Requirements. Accounting Horizons. 15(4): 373-786

Ali., Noor, M. A. \& Khurshid, M. K. 2015. Impact of Firm Size on Earnings Management; A Study of Textile Sector of Pakistan. European Journal of Business and Management. 7(28): 47-56.

Bassiouny, S. W., Soliman, M. M., \& Ragab, A. 2016. The impact of firm characteristics on earnings management: an empirical study on the listed firms in Egypt. The Business and Management Review. 7(2): 91-101

Chen, X., Kong, D., \& Wang, Y. 2013. Audit Firm Size, Earnings Management, and Information Asymmetry. China Accounting and Finance Review. 15(1)

Crasswell, A. 1998. The Association Between Quailed Opinions and Auditor Switches. Accounting and Bussiness Research. 19: 23-31.

Crisóstomo, V. L., Freire, F. de S., \& Vasconcellos, F. C. de. 2013. Corporate Social Responsibility, Firm Value and Financial Performance in Brazil. International Journal of Managerial Finance. 10(1): 1-24

DeAngelo, L. E. 1981. Auditor Size And Audit Quality. Journal of Accounting and Economics. 3(3): 183-199.

Deitiana, T. 2015. The Determinant of CSR Disclosure of Mining Industry Listed in Indonesia Stock Exchange. Journal of Doctorate Program in Management, University of Padjadjaran. 2613: 141-148.

Dumbi, Z. 2010. Pengaruh Arus Kas Bebas dan Financial Leverage terhadap Manajemen Laba. Tesis. Universitas Padjajaran, Bandung.

Effendi, M. A. 2009. The Power Of Good Corporate Governance. Jakarta: Salemba Empat.

Effendi, S., \& Daljono. 2013. Pengaruh Corporate Governance Dan Kualitas Auditor Terhadap Manajemen Laba. Journal Jurusan Akuntansi Fakultas Ekonomika dan Bisnis. Universitas Diponegoro. 2(3): 1-14. 
Faozi, K. 2003. Analisis FaktorFaktor Yang Mempengaruhi Tindakan Praktik Perataan Laba Pada Perusahaan Public Non Financial Di Indonesia. Tesis. Universitas Diponegoro

Fitria, M. 2015. Pengaruh Struktur Kepemilikan, Ukuran Perusahaan dan Kualitas Audit terhadap Manajemen Laba. Skripsi. STIESIA, Surabaya.

Gerayli, M. S., Yanesari, A. M., \& Ma'atoofi, A. R. 2011. Impact of Audit Quality on Earnings Management: Evidence from Iran. International Research Journal of Finance \& Economics. 66(66): 77-84.

Gunawan, I K., Darmawan, N. A. S., \& Purwanti, I. G. A. 2015. Pengaruh Ukuran Perusahaan, Profitabilitas, dan Leverage terhadap Manajemen Laba pada Perusahaan Manufaktur yang Terdaftar di Bursa Efek Indonesia (BEI). eJournal S1 Ak Universitas Pendidikan Ganesha Jurusan Akuntansi Program S1. 03(01): 6-10.

Healy, P. M., \& James M. Wahlen. 1999. A Review Of The Earnings Management Literature And Its Implications Of Standard Setting. SSRN Electronic Journal. 13: 365-383.

Herlambang, S. 2015. Pengaruh Good Corporate Governance dan UkuranPerusahaan terhadap Manajemen Laba. Diponegoro Journal Of Accounting. 4(3): 1-11.

Herusetya, A. 2009. Efektifitas Pelaksanaan Corporate Governance dan Audit Eksternal Auditor Dengan Spesialisasi Industri dalam Menghambat Manajemen Laba. Jurnal Akuntansi dan Auditing Indonesia, 13(2): 167-188.

Hilmi, U., \& Ali, S. 2008. Analisis Faktor-Faktor yang Mempengaruhi Ketepatan Waktu Penyampaian Laporan Keuangan (Studi Empiris pada Perusahaanperusahaan yang Terdaftar di BEJ Periode 2004-2006). Simposium Nasional.

Jahmani, Y., \& Niranjan, S. 2015. Earnings Management, Weak Internal Controls, and Firm Size. Accounting \& Taxation. 7(2); 51-64

Jensen, M. C., \& Meckling, W.H. 1976. Theory of the Firm : Managerial Behavior, Agency Costs and Ownership Structure. Journal of Financial Economics. 3(4): 305-360. 
Jiang, W., Lee, P., \& Anandarajan, A. 2008. The Association between corporate Governance and earnings Quality: Futher Evidence Using the GOV-Score. Advances in Accounting, incorporating Advanced in Internastional Accounting. 24: 191-201.

Kim, Y., Liu, C., \& Rhee, S. G. 2003. The relation of earnings management to firm size. Social Science Research Network. 3: 1-21.

Llukani, T. 2013. Earnings Management and Firm Size: an Empirical Analyze in Albanian Market. European Scientific Journal. 9(16): 1857-7881.

Luhgiatno. 2010. Analisis Pengaruh Kualitas Audit Terhadap Manajemen Laba (Studi Pada Perusahaan Yang Melakukan IPO di Indonesia). Fokus Ekonomi. 5(2): 15-31.

Manggau, A. W. 2016. Pengaruh Asimetri Informasi dan Ukuran Perusahaan Terhadap Manajemen Laba pada Perusahaan Pertambangan yang terdapat di Bursa Efek Indonesia. Jurnal Ekonomi Dan Keuangan. 13(2): 103-114.

Medyawati, H., \& Dayanti A. S. 2016. Pengaruh Ukuran Perusahaan terhadap Manajemen Laba: Analisis Data Panel. Jurnal Ekonomi Bisnis. 21(3): 142152.

Nariastiti, N. W. \&Dwi Ratnadi, N. M. 2014. Pengaruh Asimetri Informasi, Corporate Governance Dan Ukuran Perusahaan Pada Manajemen Laba. EJurnal Akuntansi Universitas Udayana 9.3. 3(10):717-727.

Nindita, C. \& Siregar, S. V. 2013. Analisis Pengaruh Ukuran Kantor Akuntan Publik Terhadap Kualitas Audit di Indonesia. Jurnal Akuntansi dan Keuangan Indonesia. 14(2): 91-104

Oktaviani, H. D. 2015. Pengaruh Ukuran Dewan Direksi, Proporsi Dewan Komisaris Independen, dan Ukuran Komite Audit terhadap Praktik Manajemen Laba pada Perusahaan Farmasi yang Terdaftar Di BEI Tahun 2009 - 2014. Skripsi. Fakultas Ekonomi Universitas Negeri Surabaya.

Pradito, H. I., \& Rahayu, S. 2015. Leverage Terhadap Manajemen Laba (Studi pada Perusahaan Manufaktur yang Terdaftar di Bursa Efek Indonesia Periode 2011-2013). E-Proceeding Of Management. 2(3): 3237-3244. 
Prasetya, Pria Juni. 2016. Pengaruh Ukuran Perusahaan terhadap Manajemen Laba dengan Pengungkapan Corporate Social Responsibility sebagai Variabel Intervening. E-Jurnal Akuntansi Universitas Udayana, 14(1): 512-538.

Purnomo B. S., \& Pratiwi P. 2009. Pengaruh Earning Power terhadap Praktik Manajemen Laba (Earning Management: Suatu Kasus pada Perusahaan Go Public Sektor Manufaktur). Jurnal Media Ekonomi. 14(1):1-13.

Putra Astika, Ida Bagus. 2010. Teori Akuntansi: Konsep-Konsep Dasar Akuntansi Keuangan. Buku Ajar Pada Fakultas Ekonomi Universitas Udayana.

Ross, S. A., Westerfield, R. W., \& Jaffe, J. 2010. Corporate Finance $9^{\text {th }}$ edition. New York: McGraw-Hill/Irwin.

Sandra, D \& Kusuma, L.W. 2004. Reaksi Pasar Terhadap Tindakan Perataan Laba dengan Kualitas Auditor dan Kepemilikan Manajerial sebagai Variabel Pemoderasi. Simposium Nasional Akuntansi VII.

Scott, W. R. 2012. Financial Accounting Theory 6th edition. Toronto. Pearson Education Canada.

Sugiarti, I. 2014. Pengaruh Kualitas Audit terhadap Manajemen Laba (Studi pada Perusahaan Perbankan di Bursa Efek Indonesia tahun 2012-2014). E-Journal Ekonomi Bisnis Dan Akuntansi. 1-8.

Sugiyono. 2014. Metode Penelitian Bisnis. Bandung: CV Alfabeta.

Tariverdi, Y., Moradzadehfard, M., \& Rostami, M. 2012. The Effect Of Earnings Management On The Quality Of Financial Reporting. African Journal of Business Management. 6(12): 4603-4611.

Theresia, D. H. 2005. Hubungan antara Good Corporate Governace dan Struktur Kepemilikan dengan Kinerja Keuangan (Studi Kasus Perusahaan yang Listing di Bursa Efek Jakarta). Simposium Nasional Akuntansi VIII. Solo.

Ujiantho, M. A., \& Pramuka, B. A. 2007. Mekanisme Corporate Governance, Manajemen Laba dan Kinerja Keuangan (Studi pada Perusahaan Go Publik Sektor Manufaktur). Simposium Nasional Akuntansi X. Makassar. 
ISSN: 2302-8556

E-Jurnal Akuntansi Universitas Udayana

Vol.22.3. Maret (2018): 1909-1935

Uwuigbe, U., Ranti, U. O., \& Bernard, O. 2015. Assessment of the Effects of Firms Characteristics on Earnings Management of Listed Firms in Nigeria. Asian Economic and Financial Review. 5(2): 218-228

Waweru, N. M., \& Riro, G. K. 2013. Corporate Governance , Firm Characteristics and Earnings Management in an Emerging Economy. Journal of Applied Management Accounting Research. 11(1), 43-64.

Whittington., et al. 2012. Principles of Auditing, and Other Assurance Services, $18^{\text {th }}$ Edition. New York: Mc-Graw-Hill. 